Article

\title{
Possibilities of Powering Military Equipment Based on Renewable Energy Sources
}

\author{
Mariusz Frączek $^{1}$ (D), Krzysztof Górski ${ }^{2, *(D)}$ and Leszek Wolaniuk ${ }^{3}$ \\ 1 Department of National Security, Pomeranian University, Arciszewskiego 22a Str., 76-200 Słupsk, Poland; \\ mariusz.fraczek@apsl.edu.pl \\ 2 Command Institute, General Tadeusz Kosciuszko Military University of Land Forces, Czajkowskiego 109 Str., \\ 51-147 Wroclaw, Poland \\ 3 Faculty of Security and Safety Research, General Tadeusz Kosciuszko Military University of Land Forces, \\ Czajkowskiego 109 Str., 51-147 Wroclaw, Poland; leszek.wolaniuk@awl.edu.pl \\ * Correspondence: krzysztof.gorski@awl.edu.pl
}

Citation: Frączek, M.; Górski, K.; Wolaniuk, L. Possibilities of

Powering Military Equipment Based on Renewable Energy Sources. Appl. Sci. 2022, 12, 843. https://doi.org/ 10.3390/app12020843

Academic Editor: Andreas Sumper

Received: 23 November 2021

Accepted: 7 January 2022

Published: 14 January 2022

Publisher's Note: MDPI stays neutral with regard to jurisdictional claims in published maps and institutional affiliations.

Copyright: (c) 2022 by the authors. Licensee MDPI, Basel, Switzerland. This article is an open access article distributed under the terms and conditions of the Creative Commons Attribution (CC BY) license (https:// creativecommons.org/licenses/by/ $4.0 /)$.

\begin{abstract}
Nowadays, the land forces of the Republic of Poland use mainly two forms of powering their equipment and military devices: by connecting various devices to the national power grid and by diesel-electric generators of individual vehicles. With the first solution, power cuts have to be taken into account. In the latter case, it is necessary to ensure large fuel deliveries on a timely manner. It entails a search for new solutions able to effectively meet the needs of an individual soldier and command posts. It has inspired engineers to work on renewable energy sources. This review paper presents a concept for photovoltaic cells usage and a concept for air turbines used to charge electric power sources of different powers for the individual needs of soldiers and command posts. Examples of solutions for mobile energy systems are presented in the research work. They were verified in terms of their suitability for military applications. The concept of using a personal device to supply power for charging batteries and elements of individual soldier equipment, including low-power radio stations, has been presented as well.
\end{abstract}

Keywords: renewable energy sources; solar panels; air turbine; energy storage; military; NATO

\section{Introduction}

All NATO armies, including Poland, are looking for innovative solutions in terms of supplying weapons and military equipment. One of the considered technologies involves the use of renewable energy sources. The current research is conducted towards the possibility of applying them together with the modern military technology. It is an innovative approach, as used generators powered with gasoline and diesel are mainly in use. The current state of affairs forces the necessity of ensuring timely deliveries of large amounts of fuel, which may cause numerous logistic problems. The analysis conducted so far indicates that electricity obtained mainly from wind power and solar energy will be the likely direction of the development of alternative power supply for troops in the areas where soldiers are stationed (and also during the implementation of combat tasks).

Nowadays various power devices can be used, If only they are based on renewable energy sources derived from water, wind or sun. These solutions have advantages and disadvantages. The practice of military units shows that the requirements related to mobility are severely limited by the use of turbines powered only by water or wind. Therefore, a wider range of focus is dedicated for solutions that allow for powering weapons and military equipment through mobile solar and wind-solar power plants as well as solar panels.

The geographical location of troops determines the possibilities of using renewable energy sources. If the number of sunny or windy days is over 200, there are conditions for using solar and wind power plants in Middle Europe. The intention of the authors is to 
present selected possibilities of using renewable energy sources for the Polish army. There are similar solutions that the authors encountered in Russia and China, or in the Middle East, but they are not taken into account as they will not be bought by NATO countries.

Technical details of the solutions constitute the area of military analysis and may only be presented as a publication with a non-confidential clause. The study is of an overview nature. One novelty of this study is the concept of using a personal photovoltaic power supply device for soldiers.

\section{Literature Review}

\subsection{The Use of Photovoltaic Cells}

Obtaining electricity from sunlight is an attractive way of powering electronic devices in areas without energy infrastructure and with limitations in securing the logistic of troops [1-3]. Photovoltaic cells would usually act as a backup power source or support the operation of diesel-electric generators. At command posts, they can support the work of a field energy system. The amount of energy obtained from photovoltaic panels depends on the area, the efficiency of panels and the amount of sunlight [4,5]. Such power systems can only be operated during the daytime, which requires the accumulation of electricity.

Batteries with different parameters are used to power devices that soldiers are equipped with (e.g., radio stations, night vision devices, GPS devices). Their working time is limited by the capacity of the batteries and the temperature at which the battery operates [6-8]. The easiest way to extend the run-time of your devices while completing tasks is to use additional power sources. However, it increases the weight of the soldier's equipment. An alternative solution to the problem is to equip troops with portable charging devices powered by photovoltaic panels. Their use in various militaries, however, requires meeting additional expectations in terms of masking, resistance to mechanical damage, resistance to weather conditions, low weight, and small geometric dimensions $[1,2,6]$.

Photovoltaic panels consist of single cells connected in various configurations $[3,9,10]$ and currently manufactured panels can be grouped according to the material they are made of and their crystal structure. Most often they are manufactured on silicon basis with a crystal and amorphous structure, less often they are made of semiconductor compounds such as halides, GaAs, InP, as well as dye and organic materials [11].

Currently conducted research is aimed at obtaining the highest possible ratio of the power recovered in a PV cell to the power of solar radiation falling on the surface of a PV cell [10-14]. The manufacturing technology of PV cells can be divided into three generations. The first generation consists of PV cells based on crystalline or polycrystalline silicon. The second-generation PV cells are made of thin-film PV cells based on amorphous silicon, polycrystalline CIS (CuInSe2), CIGS (CuInGaSe2) layers. The third generation of $\mathrm{PV}$ cells is manufactured in a multi-layer technique from materials with different energy potentials $[11,13,14]$.

Due to their surface shape, thermal properties, and color, PV panels may have features that reveal the positions of troops. Dye-sensitized solar cells (DSSC) belonging to the third generation of PV cells can eliminate that disadvantage. The efficiency of PV DSSC cells is $15 \%$ [12], and they cannot compete with silicon cells in terms of efficiency. PV DSSC cells, due to the possibility of producing them in any colors and shapes, as well as the high durability of the cells and operation at low light intensity, can be used in military applications. When considering the use of PV DSSC cells, their sensitivity to both too low and too high temperatures should be taken into account [12].

The conducted research on flexible PV cells technology is focused on thin-film cells with increased efficiency and greater structure flexibility. This allows them to be integrated with soldier's personal equipment (such as a uniform, backpack, bulletproof vest, helmet, etc.). The following solution enables maintenance-free powering of soldier's life monitoring systems and charging batteries used in low-power radio stations, GPS receivers and light sources. Flexible PV panels are mostly produced with the use of PV cells made in the amorphous silicon technology as multi-junction structures or with organic technology $[3,9,13,15]$. 
The largest producers of flexible PV cells are American companies such as Global Solar, Uni-Solar, and Power Film, which also specialize in military production [15-20].

The exposition of a PV panel to solar radiation causes its temperature to rise significantly above the ambient temperature. Figure 1 shows a PV panel exposed to solar radiation at the ambient temperature of about $15{ }^{\circ} \mathrm{C}$ with variable cloud cover. The thermographic image taken after $2 \mathrm{~h}$ of exposure to solar radiation indicates that the temperature of the PV panel differed from the ambient temperature by $12{ }^{\circ} \mathrm{C}$, leaving a clear thermal trace.

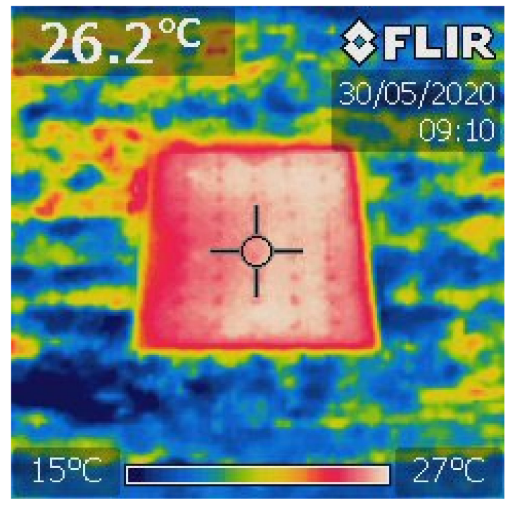

Figure 1. PV panel-thermographic image (source, prepared by the authors).

Intelligent power supply systems in military applications are becoming a feasible reality [21]. The supply of fuels intended for feeding diesel-electric units in subunits' operation areas may be difficult or even impossible. Therefore, the use of energy-saving power receivers and a hybrid power supply reduces the demand for diesel and gasoline, which translates into lower operating costs and reduction in the number of possible convoy losses [2,21]. As part of the NATO Smart Energy program, in countries such as Greece, Germany, United Kingdom, the United States and the Netherlands, intensive research is being carried out and projects for field energy systems are being developed [21-28]. Poland also wants to join the group of users of similar energy systems on a daily basis. This has resulted in an urge to present selected solutions based on solar panels, which are currently used in other NATO countries. For several years, the German Bundeswer has been equipped with Multicontanier MC66 mobile solar containers [2,29,30].

The MC66 PV system includes 66 PV panels, each with a capacity of $300 \mathrm{Wp}$, which allows for a maximum power of $19.8 \mathrm{kWp}$. Electricity is stored in a $30 \mathrm{kWh} \mathrm{LiFePo4}$ battery. The PV MC66 system can work independently as well in cooperation with the generator. Everything is stored in a standard container. The set is intended for supplying command posts and military bases $[2,29,30]$.

British troops were equipped with a compact photovoltaic power plant by Renovagen Roll-Array of the RAPID Roll system, which is produced in three power options ( $3.6 \mathrm{kWp}$, $7.2 \mathrm{kWp}$ and $11 \mathrm{kWp}$ ) [22]. The manufacturer has used the flexible PV cells technology. The RAPID Roll 11/120 system consists of a foldable PV panel with a power of $11 \mathrm{kWp}$, occupying an area of approximately $100 \mathrm{~m}^{2}$, and an energy storage with $124 \mathrm{kWh}$, using lithium-ion batteries [22]. Everything is located in the RAPID ROLL " $\mathrm{T}$ " trailer-towed by a $4 \times 4$ vehicle. The system can cooperate with field power systems powered from mobile sources of energy [2,22] and is intended to power small military bases [22]. The authors of this study had two basic questions:

1. If the lithium-ion battery is used, and the battery capacity is particularly large, how to solve the irreversible problem of overcharge and over-discharge? (There is still no clear answer since testing is still going on).

2. How to solve the possible fire and even explosion risk of battery overheating? (Fire protection measures are used at command posts). 
The described systems are intended for supplying command posts and military bases. For small sub-divisions carrying out missions and long duration, Thales Defense \& Security Inc. has designed the Expeditionary Modular Universal Battery Charger (EMUBC). This device combines the functions and capabilities of many battery chargers used by the US Army in one product $[18,19]$. The EMUBC charges electricity from the grid, from batteries, and from flexible PV panels. The charger weighs less than $3 \mathrm{~kg}$ and can be carried or installed in military vehicles.

In the United States, research is being conducted on the Soldier Worn Integrated Power Equipment System (S.W.I.P.E.S.). As part of this program, the US Army is using over 7500 sets $[18,19]$. All elements of the SWIPES system are mounted into a tactical vest.

The system includes the following: a power distribution unit (Hub), two battery charging stations for Motorola and Harris radios, a GPS DAGR charging cable, power sources in the form of Zinc-Air batteries with a voltage of $12 \mathrm{~V}$ and a capacity of $24 \mathrm{Ah}$ (whose main advantage is the ability to work in a temperature range between $-20{ }^{\circ} \mathrm{C}$ and $+60{ }^{\circ} \mathrm{C}$, as well as providing resistance to mechanical damage including bullet holes) [19]. Instead of Zinc-Air batteries, it is possible to use lithium batteries or a flexible PV panel [19].

In Poland, research on the use of PV panels in military applications has been initiated at the Military Institute of Engineer Technology (WITI-Military Institute of Engineer Technology, Obornicka 136 Str., 50-961, Wroclaw, Poland) [1,8]. As a part of this research, PV panels prototypes were designed and manufactured. There were portable for a single soldier and transportable for powering devices (e.g., communications, electronics) that are equipped with combat vehicles [31].

Greece has also been involved in the development of power systems, and its troops are equipped with a photovoltaic power plant by the Intracom Defense Electornic-IDE company. It is an autonomous, hybrid power system consisting of six PV panels with a total power of $3 \mathrm{kWp}$ placed in transport boxes and a generator with a power of $20 \mathrm{~kW}$. The set was designed to power Greek military units located in places with no access to power grids $[27,28]$.

\subsection{Application of Solar-Wind Power Plants}

Mobile solutions are an interesting and dynamically developing sort of renewable energy system. In this group, there are some promising hybrid solutions enabling the simultaneous electricity generation using both solar and wind energy, which significantly increases their reliability in various weather conditions. The mobility of such devices additionally extends the scope of their applications, dominated by power supply, including military communication systems [32] or small residential installations located in places without power grid access. Mobile solar-wind power plants are generally solar-wind electricity generators of a design and characteristics enabling them to be easily moved by available transportation means. The components of such sets are featured with a high integration degree of the functional system elements (Figure 2), which means that they consist of a small number of parts that can be easily connected by a person with little experience.

A solar-wind electricity generation system (hybrid generator) that generates electricity consists of mechanical-electrical components with their control systems and electronic circuits connected to them. They convert the generated current to a form that allows charging of batteries using an inverter to convert direct current into alternating current with characteristics matching the devices powered from it. Each system also includes cables for connecting the components, a set of electricity accumulators, and systems for distributing the generated direct and alternating current. The key parts of each set are mechanical and electrical devices that enable the conversion of energy obtained from external factors into electricity [31]. Due to the specifics of each set, these generator components determine the basic features of the entire hybrid system (i.e., the dimensions, efficiency, characteristics of the generated current, operational stability, the possibility of mobile use etc.). Each solar-wind power generation system (Figure 3) consists of four key functional blocks: 
wind electricity (BEW), light electricity (BES), generated energy accumulation (BAE), and distribution of generated electricity (BDE).

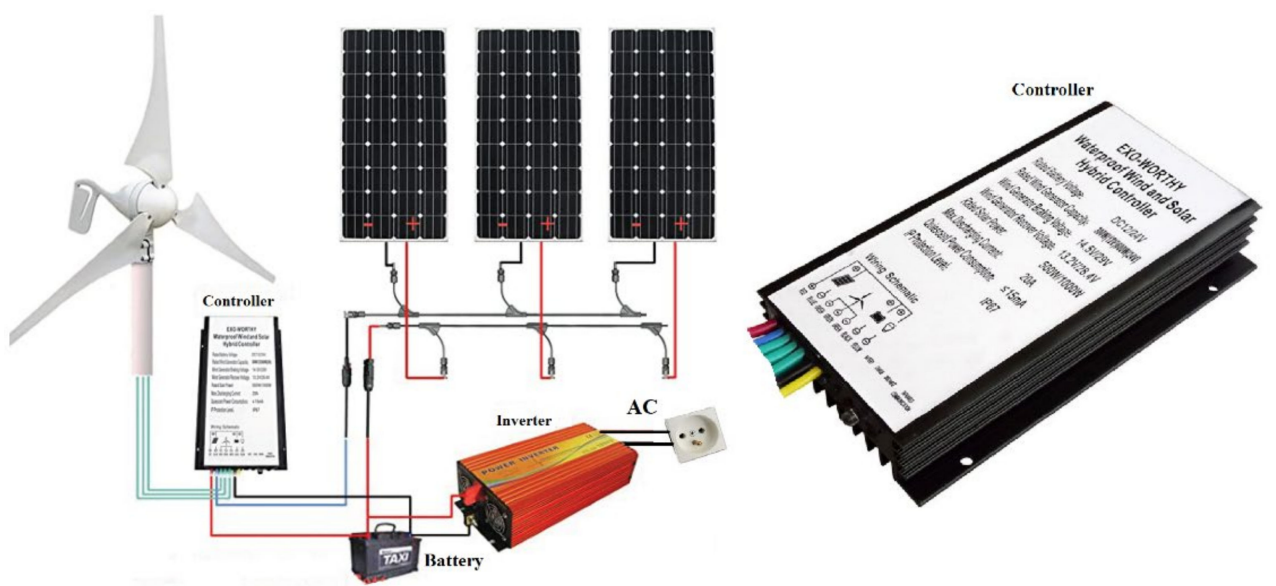

Figure 2. A kit example for mounting a hybrid generator (source, prepared by the authors).

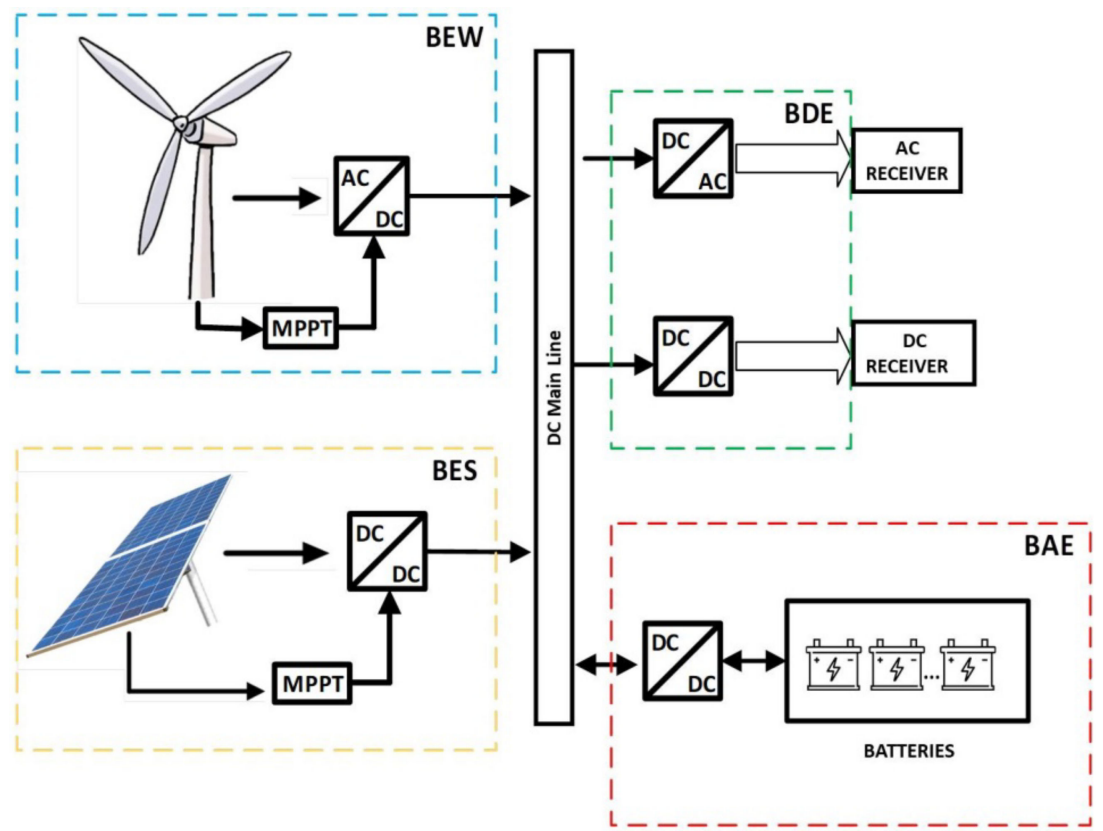

Figure 3. General operation scheme of a solar-wind power generator system (source, prepared by the authors).

\subsection{Operational Rules}

The main, shared medium of electricity transmission in a standard generator is the DC magistrate shown in the Figure 3 (hereafter referred to as the DC magistrate).

Electricity generated in BEW and BES via the DC magistrate is accumulated in BAE and supplies the receiving devices via the BDE. In case of insufficient or a lack of energy generated by BEW and BES units, the current flows from the BAE to the DBE. In case it is necessary to ensure the continuity of electricity supply to receivers connected to $\mathrm{BDE}$, and in the absence of energy generated continuously and stored in the BAE, electricity must be generated by a generator using non-renewable sources [32].

Electronic circuit modules used in the described system are used to convert electricity and optimize the operation of solar panels and wind turbines. In order to obtain a common power source for external receivers in a hybrid system combining wind and photovoltaic model, it is necessary to include a power converter that converts alternating current (AC) 
into direct current (DC) or vice versa. DC systems are also essential for adjusting the current-voltage parameters to a level set for a given system implementation [33,34].

The main part of BEW is a wind turbine that converts the kinetic energy of the wind into mechanical energy and then into electricity. It is worth noting that it produces alternating current. Wind turbines can be classified into two types based on the axis around which the turbine rotates. Turbines rotating around a horizontal axis are more common in real life systems. In modern solutions, there is a large variety of forms of such mechanisms. The use of a specific shape and the choice of the rotor operation axis is related to the specific environment in which the generator is supposed to operate.

The most important parameter influencing the power generated by the wind energy conversion system is its speed, the size of which is proportional to both the effective rotor surface and the cube of the wind speed. Most manufacturers claim that their devices generate electricity at low wind speeds. However, the theoretical basis and mathematical calculations show that for most solutions, acceptable power is only generated at speeds between $20-27 \mathrm{~km} / \mathrm{h}$. It is assumed that turbines with such wind generate only $1 / 8$ of their maximum power, which means that, for example, an 800-watt turbine in such conditions produces only $100 \mathrm{~W}$ of power [35]. In BEW, the Maximum Power Point Tracking (MPPT) system, also referred to as the advanced maximum power point tracking system, is responsible for reducing the negative impact of wind speed fluctuations on the stability of the generated electricity parameters, which can increase the amount of energy obtained by up to $20 \%$ (in relation to the inverter without MPPT). The main task of such system is to "track" this point and adjust to its new value as quickly as possible by reducing or increasing the rotational speed of the turbine. The operation of such systems is often improved with the use of the latest solutions in the field of computer technology (e.g., neural networks) [36,37].

The rectifier in the BEW converts the alternating current generated by the turbine into a direct current source using power diodes or by controlling the ignition angles of controllable switches. The BEW produced this way should have the characteristics required to be fed to the DC Magistrate.

\subsection{Solar Electricity Generator}

In case of the BES block, it is worth noting that the photovoltaic panels already generate the direct current. However, in some implementations this requires the use of a DC/DC converter system in order to obtain the current with the desired parameters. Here as well, in the BES block, the MPPT module is implemented. It uses the latest technology when it comes to the control of electromechanical systems [36]. The DC/DC converter in this block has the functionality extended by:

1. CC charging control (i.e., preventing loopback from batteries to photovoltaic panels modules).

2. Automatic shutdown of the block if the voltage level from the panels is too high or too low.

3. Automatic restart after returning to the appropriate operating parameters, protection against short-circuit or overload, etc.

4. Electricity accumulation block.

The level of reliability and efficiency of the hybrid electricity generator is largely defined by the operational reliability of BAE (i.e., the unit responsible for storing the generated BWE and BSE energy). Among the various electricity storage devices, batteries are the most widely used, so the correct selection of them is crucial. Therefore, it should be clearly pointed out which type of battery should be selected for military purposes, such as lithium-ion battery, lead-acid battery, solid-state battery, etc.

The batteries must be able to handle the peak power needed during the operation of the entire generator and provide sufficient power at a nominal load for the time assumed for the device $[24,33]$. At the same time, it is worth noting that they are probably the most important part that should be taken into account when considering the mobility of the 
entire system due to the fact that a specific feature of even the latest solutions in this field is their heavy weight and considerable dimensions. An interesting analysis of this problem has been presented in [33].

In the BDE electricity distribution block, the key parts are:

1. A DC/AC converter, also called the inverter, converting direct current into alternating current $(230 \mathrm{~V}, 50 \mathrm{~Hz}$ in Europe), which is acceptable to receivers. Such a system should also include functionalities related to protection against a generator overload, unfavorable loopback during energy consumption and automation systems responding to improper current-voltage parameters of the supplied electricity.

2. A set of AC and DC sockets for distribution of electricity generated by the system.

Electricity generators are installations called solar-wind mobile power plants, solarwind power mobile generators, and solar-wind portable generators, available in versions that enable the production and storage of electricity from about 1 up to $100 \mathrm{~kW}$ power. When used in an area with adequate sunlight and proper air movement characteristics, they are able to provide electricity $24 \mathrm{~h}$ a day, 7 days a week. This is the result of the authors' direct observations during land forces exercises at command posts. Often, these installations are equipped with various systems for remote control and component control via extensive computer networks. They do not require direct supervision, which significantly increases their functionality and applicability.

Among the devices of this type available on the market, you can find both sets of autonomous solutions offered with parts ensuring mobility, as well as modular installations consisting of ready-made components that enable the generation and storage of electricity from both wind and sunlight. These can be adapted to one's own needs and for possibilities offered by the range of displacement of the entire hybrid system.

Among the large comprehensive solutions, one of the most interesting is the German offer [35] presenting a product called Solarcontainer. It is a wind-solar container power plant equipped with an autonomous optimization system of power generation and a remote monitoring and control system for its operation. It consists of a set of six wind generators with a power of $1 \mathrm{~kW}$ each and photovoltaic panels generating up to $55 \mathrm{kWp}$. It also has a battery system that allows the store of up to $75 \mathrm{kWh}$ of electricity. The following set weighs about 10 tons and can be set up in $30 \mathrm{~min}$.

Presented below is the Canadian MOBISMART Hybrid Off-grid Wind and Solar Power Generator (Figure 4) [38]. This represents an example of smaller and cheaper solution that is also more interesting for the inhabitants of the northern hemisphere.

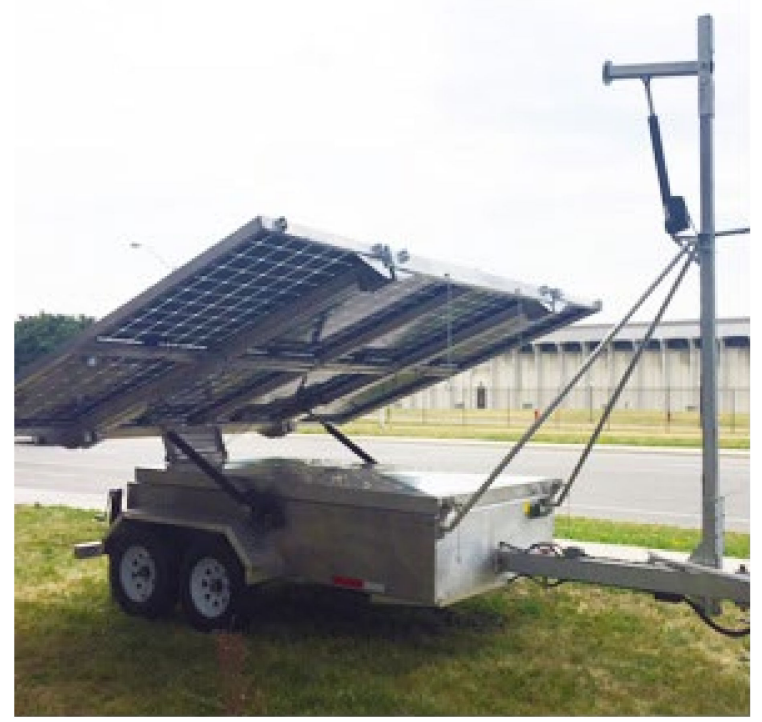

Figure 4. Mobile solar-wind power plant by MOBISMART (source, https: / / mobismart.ca / mobilehybrid-wind-solar-system (accessed on 12 November 2021)). 
The kit is installed on an aluminum trailer that can be connected to any car. It allows one to generate up to $6 \mathrm{kWp}$ of power and is equipped with an energy storage kit allowing up to $30 \mathrm{kWh}$ (Lux model). An installed wind turbine generating up to $1 \mathrm{kWp}$ (vertical axis) or $1.2 \mathrm{kWp}$ (horizontal axis operation).

The mobile energy management system (MEMS) from the German company PFISTERER integrates a conventional source of electricity in the form of a power generator with various renewable energy sources. The MEMS consists of two ZSEs with a power of $10 \mathrm{~kW}$ each, a wind turbine with a maximum capacity of $5 \mathrm{kWp}$, PV panels with a maximum capacity of $5 \mathrm{kWp}$, and an energy storage $60 \mathrm{kWh}$. Additionally, the system can be supplemented with Austrian Smartflower sets with a maximum power of $2 \mathrm{kWp}$ and the PV MC66 system [2,20,39].

In the solutions related to the described systems, modular power supply systems play an important role, enabling the construction of their own structures dedicated to the specific needs of the user. They secure specific capacities in terms of electricity demand and offer solutions related to the mobility of structures (dimensions, shock resistance, etc.). The existing commercial offers of solutions in the field of small wind turbines, solar panels and is wide, but not every device is suitable for military applications.

All of the autonomous hybrid generators presented above can be combined into larger structures, thus obtaining energy systems with greater powers. The MOBISMART company offers a solution consisting of connected generators giving a total of approx $200 \mathrm{kWp}$ of electricity and dedicated to power a small container estate in Canada.

\subsection{Personal Photovoltaic Power Device Application Concept}

The development of flexible photovoltaic panels technology means that they have even higher efficiency, mechanical strength, and a lower price. For the concept of building a personal power supply device (RUPD) it is likely that one would use a flexible PV panel. OUZ is designed to charge power sources for devices that soldiers are equipped with, such as a low-power personal radio (e.g., R3501, GP340 radiotelephone, light sources, or GPS). It was assumed that the proposed solution will have a modular structure able to be freely configured depending on the user's needs. The diagram block is presented in Figure 5.

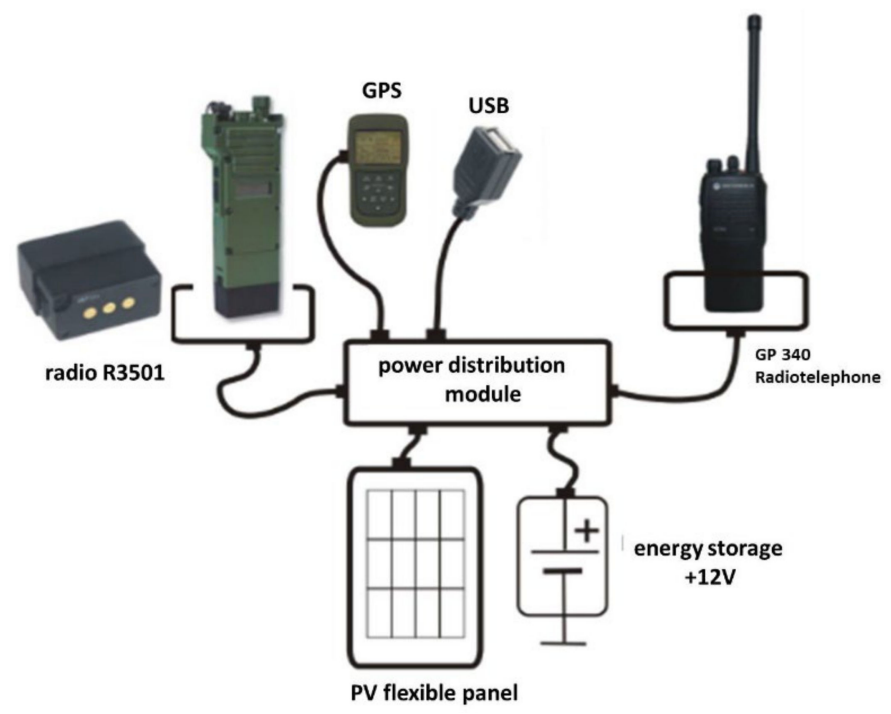

Figure 5. Block diagram of the personal power device (source, prepared by the authors).

The personal charging device will consist of the following blocks:

1. Power distribution module;

2. Energy storage;

3. Flexible PV panel;

4. A charging module that powers: 


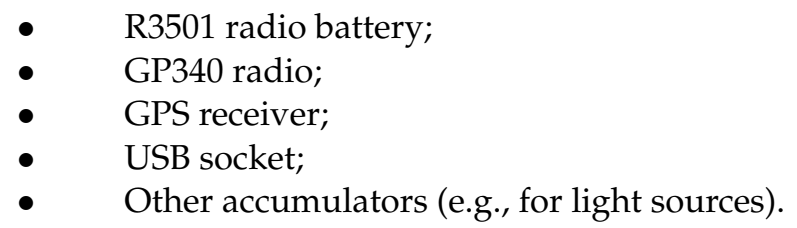

The individual parts should be attached to the power distribution module with flexible hoses having connectors meeting MIL standards. The PDM module is the central element of the system; it integrates all parts of the system. The module's task is to distribute the power from the energy storage and the PV panel to the equipment used, depending on their energy needs. The energy storage system is a battery that has been selected as the basic criterion for the ratio of its capacity to its weight. Another criterion is the resistance of the battery to weather conditions, mechanical shocks, and shocks themselves. The main source of power is supplemented by a flexible PV panel, which should be folded or rolled up for transport. PDM is equipped with dedicated cables for charging one type of terminal device battery, for example the R3501 radio battery, another for charging the radio (e.g., GP340). The USB socket provides $+5 \mathrm{~V}$ for charging other electronic devices.

\subsection{Reference to Economic and Environmental Aspects of Application Renewable Energy Sources}

Currently, there are several different types of gasoline- or diesel-powered generators in the land forces. Their use depends on the level of command. Small and low-powered ones burn 1.5 to $2 \mathrm{~L}$ of fuel during one hour of operation. Their output is about $4 \mathrm{~kW}$. Medium power generators are already consuming fuel from 8-12 L. Their power is about $16-30 \mathrm{~kW}$. Large generators need more than $20 \mathrm{~L}$ of fuel for one hour of operation. Operational documentation states that each of the above generators can work up to twenty hours without interruption. In the first case, this is a fuel consumption of 30 to $40 \mathrm{~L}$; in the second case from 160 to $240 \mathrm{~L}$; and in the third case at least $400 \mathrm{~L}$. You have to pay 36-48 Euro for fuel, 192-288 Euro, and 480 Euro in the last example assuming that $1 \mathrm{~L}$ of fuel costs 1.2 Euro. The economic calculation increases in direct proportion with the increase in the number of power generators. Therefore, analyses are carried out not only to reduce the above-mentioned costs, but also to care for the environment by reducing emissions of harmful fumes into the atmosphere. Such an alternative to the military are modern solutions concerning renewable energy sources and, according to the authors, should be the subject of analysis and research.

\section{Conclusions}

Currently, significant development and innovations in the use of renewable energy sources is ongoing, especially with regard to mobile solar-wind power plants and the use of photovoltaic panels. Various sectors of the economy, groups of people, and various organizations are interested in solutions in this field. Unique structures and solutions are created to improve the efficiency of systems, as well as to develop the possibilities of putting them in use and reducing the production costs. The economic evaluation of the use of renewable energy sources shows the disadvantages and advantages of such a solution. The main disadvantages are:

1. High dependence on weather conditions.

2. Solar panels cannot be charged at night.

3. Power plants should have shock resistance and a construction that will provide protection against mechanical damage.

4. It should take up to $10 \mathrm{~min}$ for the power plant to start up.

5. The service is for a maximum two soldiers.

Advantages of using solar-wind generators:

1. Independence from power grid infrastructure.

2. Mobility of solutions. 
3. Economy of gasoline or oil used today by power generators, which may use 4-20 L during an hour of operation (depending on the power). With $20 \mathrm{~h}$ of operation, you save 80-400 L of fuel per day for one piece of equipment (cost 100-500 Euro/day).

4. No need to refuel generators with fuel.

5. No noise during operation.

6. Protection of the natural environment.

7. Charged batteries can be used multiple times.

8. Provision of power for the soldier's armaments and military equipment as well as command posts.

According to the authors, the cost of implementing renewable energy sources should allow for significant fuel savings. The simple design of the devices will result in their quick repair or replacement of damaged elements. It is likely that their use will become widespread. Research is underway on solutions that are very light and mobile and will provide energy. Their availability will depend on the price and needs of soldiers.

The study reviews contemporary solutions in the field of photovoltaic panels and mobile solar-wind power plants, which have either generated the interest of various armies or are already operational. Their task is to provide electricity based on renewable energy sources and primarily for the various parts of command posts. These systems are used by the armed forces of Germany, the United Kingdom, Greece, and the USA. Along with the development of technology, solutions are chosen to enable the development of large-area and high-power mobile power systems in a short time. The concept of a personal power supply device for a soldier has been presented. Attention has been focused on unmasking the possibilities of PV panels, which leave a clear thermal trace during operation. Further research envisages the development of a personal power supply device, the construction of a model for this device, and field tests of the model by soldiers.

Author Contributions: M.F. supervised the investigations and took part in elaboration of the article conceptualization, investigation methodology, and writing the article. K.G. and L.W. performed measurements and took part in elaboration of the article conceptualization, K.G. and L.W. validation of the model and writing the article. All authors have read and agreed to the published version of the manuscript.

Funding: This research received no external funding.

Institutional Review Board Statement: Not applicable.

Informed Consent Statement: Not applicable.

Data Availability Statement: Not applicable.

Conflicts of Interest: The authors declare no conflict of interest.

\section{References}

1. Szczepaniak, M.; Maleczek, S. Militarne systemy fotowoltaiczne. Napędy I Sterow. 2017, 19, 124-127.

2. OZE w Służbie NATO-GLOBEnergia. Available online: https://globenergia.pl/oze-w-sluzbie-nato/ (accessed on 11 November 2021).

3. Maleczek, S.; Malicki, W.; Drabczyk, K.; Cebrat, A. Badanie elastycznych paneli fotowoltaicznych w aspekcie zastosowań militarnych. Elektron. Konstr. Technol. Zastos. 2014, 55, 55-58.

4. Krac, E.; Górecki, K. Wpływ Wybranych Parametrów Pogodowych Na Charakterystyki Paneli Fotowoltaicznych. Elektron. Konstr. Technol. Zastos. 2016, 1, 42-45. [CrossRef]

5. Dyvak, M.; Górecki, K.; Zarebski, J.; Porplytsya, N.; Dqbrowski, J.; Krac, E. Mathematical Model of Weather Conditions Influence on Properties of Photovoltaic Installation and Method of Its Identification. In Proceedings of the 2019 9th International Conference on Advanced Computer Information Technologies (ACIT), Ceske Budejovice, Czech Republic, 5-7 June 2019; pp. 35-39.

6. Adamczyk, A. Zastosowanie Profili Energetycznych w Systemach Tactical Nanogrid Do Obniżenia Masy Mobilnego Hybrydowego Źródła Zasilania. Ph.D. Thesis, Akademia Morska w Gdyni, Gdynia, Poland, 2018.

7. SWIPES. Available online: https:/ / www.efbpower.com/catalog/swipes/ (accessed on 12 November 2021).

8. Szczepaniak, M.; Maleczek, S. Systemy fotowoltaiczne do zastosowania w aplikacjach militarnych. Masz. Elektr. Zesz. Probl. 2017, 1, 73-79. 
9. Maleczek, S.; Szczepaniak, M.; Malicki, W.; Drabczyk, K. Zastosowanie polikrystalicznych ogniw krzemowych jako elastycznych pokryć fotowoltaicznych. Napędy I Sterow. 2019, 21, 103-108.

10. Malicki, W.; Miedziński, B.; Rutecki, K.; Habrych, M. Ogniwa fotowoltaiczne w elektrycznych instalacjach zasilających. Mech. Autom. Gór. 2010, R. 48, 121-125.

11. Pietrusza, R.A. Otrzymywanie i Charakteryzacja Ogniw Fotowoltaicznych Zawierajacych Cienkie Warstwy Oraz Nanosłupki Tlenku Cynku. Ph.D. Thesis, Instytut Fizyki PAN, Warszawa, Poland, 2015.

12. Szindler, M.; Szindler, M. Barwnikowe ogniwa fotowoltaiczne z polielektrolitem. Przeglad Elektrotechniczny 2018, 94. [CrossRef]

13. Klugmann-Radziemska, E. Technologiczny postęp w fotowoltaice. Czysta Energ. 2014, 5, 40-42.

14. Korasiak, P. Sprawność konwersji promieniowania słonecznego na energię elektryczną współczesnych ogniw i modułów fotowoltaicznych. Przeglad Elektrotechniczny 2017, 93, 47. [CrossRef]

15. Uni-Solar, Technical Data. Available online: http://www.uni-solar.com/wp-content/uploads/2011/11/PB_ePVL_Technical_ Data_Sheet_EN_-AA6-3624-04-.pdf (accessed on 19 May 2020).

16. Man-Portable I PowerFilm Solar Inc. Available online: https://www.powerfilmsolar.com/markets/government-dod-solutions/ man-portable (accessed on 12 November 2021).

17. Government \& DoD I PowerFilm Solar Inc. Available online: https://www.powerfilmsolar.com/markets/government-dodsolutions / (accessed on 12 November 2021).

18. 7 Watt Rollable Solar Panel (R-7). Available online: https:/ /www.powerfilmsolar.com/products/7-watt-rollable-solar-panel (accessed on 12 November 2021).

19. IDE-INTRACOM Hybrid-Power-Systems/Żródło. Available online: https://www.intracomdefense.com/hybrid-power-systems (accessed on 21 May 2020).

20. Soledion-Multiconsolar, Microgrid. Available online: https://soledion.com/images/multiconsolar/microgrid-2.jpg (accessed on 22 May 2020).

21. Ducaru, S. Smart Energy for Military Forces is becoming a realityby. Eur. Secur. Def. Union ESDU 2015, 20, 39-40.

22. RAPID ROLL Instant Deployable Solar Power. Available online: http:/ /www.renovagen.com/wp-content/uploads/2018/04/ Renovagen_Brochure.pdf. (accessed on 12 November 2021).

23. Hybridization \& Energy Storage Systems-INTRACOM DEFENSE. Available online: https://www.intracomdefense.com/hybridpower-systems/hybridization-energy-storage-systems/ (accessed on 12 November 2021).

24. Tactical Hybrid Generators-INTRACOM DEFENSE. Available online: https://www.intracomdefense.com/hybrid-powersystems/tactical-hybrid-generators/ (accessed on 12 November 2021).

25. Solar-Container for NATO. Available online: https://solarcontainer.info/home-2/solar-container-2/solar-container\%20for\%20 nato-2.html (accessed on 11 November 2021).

26. Library, N. NATO LibGuides: Smart Energy: Journal Articles. Available online: https://natolibguides.info/smartenergy/articles (accessed on 11 November 2021).

27. Zotos, A. Hybrid Smart Energy Systems. Eur. Secur. Def. Union ESDU 2015, 20, 44.

28. Havre, A. Smart energy for secure communications. Eur. Secur. Def. Union ESDU 2015, $20,45$.

29. Solutions-SOLAR CONTAINER. Available online: https:/ / www.solarcontainer.at/solutions / (accessed on 12 November 2021).

30. Znajdek, K. Elastyczne Ogniwa Fotowoltaiczne. Ph.D. Thesis, Politechnika Łódzka, Łódź, Poland, 2014.

31. Patel, M.R. Wind and Solar Power Systems: Design, Analysis, and Operation, 2nd ed.; Taylor \& Francis: Abingdon, UK, 2006; ISBN 978-0-8493-1570-1.

32. Paska, J.; Biczel, P. Hybrid Photovoltaic-Fuel Cell Power Plant. In Proceedings of the 2005 IEEE Russia Power Tech, St. Petersburg, Russia, 30 July 2005; pp. 1-5.

33. Dawidowicz, E.; Podlesak, T.; Leung, F. Mobile Hybrid Power System Elements. In Proceedings of the SAE 2012 Power Systems Conference, Phoenix, AZ, USA, 30 October 2012; Volume 1.

34. Nair, A.; Murali, K.; S.P., A.; Arjunan, C.V. Modelling and Optimising the Value of a Hybrid Solar-Wind System. IOP Conf. Ser. Mater. Sci. Eng. 2017, 197, 012035. [CrossRef]

35. Ahmed, A.; Mahmood, D.Y.; Er, Z.; Alqaisi, Z. Hybridization of Solar/Wind Energy System for Power Generation in Rural Aeras. Acta Phys. Pol. A 2016, 130, 434-437. [CrossRef]

36. Prakash, N.; Ravikumar, R.; Gnanambal, I. A Stand Alone Hybrid Power Generation System by MPPT Control Based on Neural Networks. Int. J. Sci. Res. IJSR India Online 2012, 1, 9.

37. Samrat, N.; Ahmad, N.; Choudhury, I.; Taha, Z. Technical Study of a Standalone Photovoltaic-Wind Energy Based Hybrid Power Supply Systems for Island Electrification in Malaysia. PLoS ONE 2015, 10, e0130678. [CrossRef]

38. Mobile Hybrid Wind \& Solar Power System. Available online: https://mobismart.ca/mobile-hybrid-wind-solar-system/ (accessed on 12 November 2021).

39. NATO Smart Energy Capable Logistician 2015; Hungary, 19 June 2015. Available online: https://www.nato.int/cps / en/natohq/ news_120481.htm (accessed on 10 May 2021). 